Research Paper

\title{
Campylobacter jejuni in commercial eggs
}

\author{
Belchiolina Beatriz Fonseca, ${ }^{1,2}$, Marcelo Emílio Beletti ${ }^{2}$, Roberta Torres de Melo ${ }^{1}$, \\ Eliane Pereira Mendonça ${ }^{1}$, Letícia Ríspoli Coelho ${ }^{1}$, Priscila Christen Nalevaiko ${ }^{1}$, \\ Daise Aparecida Rossi ${ }^{1}$ \\ ${ }^{1}$ Laboratório de Biotecnologia Animal Aplicada, Faculdade de Medicina Veterinária, \\ Universidade Federal de Uberlândia, Uberlândia, MG, Brazil. \\ ${ }^{2}$ Instituto de Ciências Biomédicas, Universidade Federal de Uberlândia, Uberlândia, MG, Brazil.
}

Submitted: July 31, 2012; Approved: September 9, 2013.

\begin{abstract}
This study evaluated the ability of Campylobacter jejuni to penetrate through the pores of the shells of commercial eggs and colonize the interior of these eggs, which may become a risk factor for human infection. Furthermore, this study assessed the survival and viability of the bacteria in commercial eggs. The eggs were placed in contact with wood shavings infected with $C$. jejuni to check the passage of the bacteria. In parallel, the bacteria were inoculated directly into the air chamber to assess the viability in the egg yolk. To determine whether the albumen and egg fertility interferes with the entry and survival of bacteria, we used varying concentrations of albumen and SPF and commercial eggs. C. jejuni was recovered in SPF eggs (fertile) after three hours in contact with contaminated wood shavings but not in infertile commercial eggs. The colonies isolated in the SPF eggs were identified by multiplex PCR and the similarity between strains verified by RAPD-PCR. The bacteria grew in different concentrations of albumen in commercial and SPF eggs. We did not find C. jejuni in commercial eggs inoculated directly into the air chamber, but the bacteria were viable during all periods tested in the wood shavings. This study shows that consumption of commercial eggs infected with $C$. jejuni does not represent a potential risk to human health.
\end{abstract}

Key words: campylobacteriosis, commercial eggs, penetration.

\section{Introduction}

Campylobacter jejuni are among the most common causes of human bacterial diarrhea in developed countries (EFSA, 2009). The prevalence of these bacteria in poultry is high, and the consumption of contaminated chicken is the main risk factor for consumers (Humphrey et al., 2007).

Gastroenteritis caused by infection with C. jejuni in humans is usually self-limiting, causing diarrhea, abdominal pain, and fever, in the course of 5 to 7 days. In rare cases, it can trigger Guillain-Barre syndrome, a severe paralysis form in which the patient has neurological disorders (Altekruse et al., 1999; Moore et al., 2005).

The epidemiology of campylobacteriosis in poultry is very discussed and poorly understood (Sahin et al., 2003). Despite the recognition that the consumption of contami- nated chicken is responsible for a large number of instances of human campylobacteriosis, the involvement of other poultry products such as eggs is not yet fully understood.

A better understanding about the eggs role in the spread of C. jejuni is necessary. This is because the physiological characteristics of the egg and the bacteria may allow entry of the microorganism to the egg's interior. If these microorganisms penetrate and multiply inside commercial eggs, the consumption of this food can pose a risk to human health. However, it is known that the albumen has several defenses against microbial organisms that can invade the contents of the egg immediately after oviposition (Baker et al., 1987), thus blocking the passage and survival of such organisms inside the eggs. 
The objective of this study was to evaluate the ability of $C$. jejuni to penetrate the pores of the shells of commercial eggs and colonize the interior of these eggs.

\section{Materials and Methods}

For this study, the $C$. jejuni subsp. jejuni (IAL 2383) strain was used. This strain was isolated from a human outbreak, characterized, and deposited in the Bank of Cultures of the Instituto Adolfo Lutz, São Paulo (IAL, Brazil). This strain expresses the key genes associated with the virulence of $C$. jejuni in humans and birds (data not shown).

To determine whether $C$. jejuni penetrated into the interior of eggs, we used wood shavings that previously had been sterilized and then artificially contaminated with $10^{5}$ $\mathrm{cfu} / \mathrm{g}$ of $C$. jejuni (IAL 2383). The culture was diluted in Bolton broth supplemented with 5\% bovine blood hemolysate and used to coat the shavings. For the control group, sterile shavings were coated with Bolton broth supplemented with $5 \%$ bovine blood hemolysate without bacteria. For the control group, we used 90 commercial eggs (infertile), and for the test group we used 300 commercial eggs (infertile). Before the start of the experiment, we analyzed three samples (each of 10 eggs) to ensure that each lot had not previously been infected with $C$. jejuni.

The eggs from different groups were arranged in individual containers for each treatment. A layering arrangement was used, interspersing the eggs with the shavings, and the eggs were maintained at room temperature (about $25^{\circ} \mathrm{C}$ ) until the analysis. Time points for sample processing were set at 3, 7, and $24 \mathrm{~h}$ of contact. For each time period, the egg yolk from 100 test eggs and 30 control eggs were collected for analysis. A sample of shavings from each group was collected at each time period to check for the viability of the bacteria.

The egg yolks and shavings were analyzed by traditional cultivation on plates and real-time PCR.

To verify if the type of egg (fertile or infertile) influences the passage or survival of $C$. jejuni, we performed the same experiment described above with commercial eggs (infertile) on $180 \mathrm{SPF}$ eggs (fertile) (a 90-test group and 90-control group).

To check the viability of the bacteria inside the infertile eggs, we used 120 commercial eggs: 60 for the test group and 60 for the control group. Treated eggs were inoculated with $0.1 \mathrm{~mL}$ of saline $(8.5 \mathrm{~g} \mathrm{NaCl} / \mathrm{L})$ containing $10^{5}$ cfu of $C$. jejuni IAL 2383. The inoculum was introduced into the air space at the superior pole using a sterile hypodermic needle $(0.3 \mathrm{~mm} \times 13 \mathrm{~mm})$, without disrupting the chorioallantoic membrane. The control eggs were inoculated in the same manner and with the same solution but without the bacteria. After periods of 3, 7, and $24 \mathrm{~h}$ of inoculation, the egg yolk were collected for analysis by traditional cultivation on plates and real-time PCR.

To check if the albumen inhibits the growth of $C$. jejuni, $10^{5} \mathrm{UFC} \mathrm{g}^{-1}$ strain (IAL2383) diluted in saline $(8.5 \mathrm{~g}$
$\mathrm{NaCl} / \mathrm{L}$ ) was inoculated in different concentrations of commercial and SPF egg albumen diluted in Bolton broth (Oxoid) supplemented with 5\% equine blood hemolysate (Table 1). The samples were cultivated on solid mCCDA media (Oxoid) under microaerobic conditions (Probac microaerobic generator) in anaerobic jars at $37{ }^{\circ} \mathrm{C}$ for $48 \mathrm{~h}$ prior to being counted.

In the Applied Animal Biotechnology Laboratory of the Federal University of Uberlândia (LABIO-UFU), $1 \mathrm{~mL}$ of egg yolk and vitelli from each sample taken from commercial and SPF eggs, respectively, was added to $9 \mathrm{~mL}$ of Bolton broth (Oxoid) and immediately analyzed for the presence of $C$. jejuni by real-time PCR assay. In parallel, the samples were pre-enriched under microaerobic conditions (Probac microaerobic generator) at $37^{\circ} \mathrm{C}$ for $24 \mathrm{~h}$ for subsequent cultivation on solid mCCDA medium (Oxoid).

The real-time PCR assay used the BAX System (Dupont, Wilmington, DE) according to the manufacturer's recommended procedures (Users Guide BAX®System, 2007). In the laboratory, $5 \mathrm{~mL}$ samples of collected medium (Bolton broth) were transferred to microtubes containing $200 \mathrm{~mL}$ of lysis solution. The mixture was heated at $37^{\circ} \mathrm{C}$ for $20 \mathrm{~min}$ and $95^{\circ} \mathrm{C}$ for $10 \mathrm{~min}$, and then it was transferred to a cooling block $\left(2^{\circ} \mathrm{C}\right.$ to $\left.8^{\circ} \mathrm{C}\right)$ for $5 \mathrm{~min}$. After cooling, $30 \mathrm{~mL}$ of lysate were transferred to PCR tubes containing the primers for C. jejuni, C. coli, and C. lari and the other reagents needed for PCR assay. The tubes were transferred to the thermocycler/detector and the pre-established program for the hardware followed. At the end of the amplification and detection cycles, the equipment automatically issued the results, identifying the species and number as $\mathrm{cfu} / \mathrm{g}$. The ATCC 33291 strain of C. jejuni was processed in parallel as a positive control.

The Bolton broth (Oxoid) preenriched samples were inoculated onto mCCDA (Oxoid,) agar with $16.0 \mathrm{mg}$ of cefoperazone, $5.0 \mathrm{mg}$ of amphotericin B antibiotic supplement (Oxoid), and 5\% bovine blood hemolysate. The plates

Table 1 - Different concentrations of albumen in Bolton broth for the antimicrobial test.

\begin{tabular}{lccc}
\hline $\begin{array}{l}\text { Albumen } \\
\mathrm{mL} /(\%)\end{array}$ & $\begin{array}{r}\text { Bolton } \\
(\mathrm{mL})\end{array}$ & $\begin{array}{r}\text { Blood } \\
(\mathrm{mL})\end{array}$ & $\begin{array}{c}\text { C. jejuni IAL } \\
2383(\mathrm{~mL})\end{array}$ \\
\hline $1(9.4)$ & 9 & 0.5 & 0.1 \\
$2(18.9)$ & 8 & 0.5 & 0.1 \\
$3(28.4)$ & 7 & 0.5 & 0.1 \\
$4(37.7)$ & 6 & 0.5 & 0.1 \\
$5(47.2)$ & 5 & 0.5 & 0.1 \\
$6(56.6)$ & 4 & 0.5 & 0.1 \\
$7(66.0)$ & 3 & 0.5 & 0.1 \\
$8(75.5)$ & 2 & 0.5 & 0.1 \\
$9(84.9)$ & 1 & 0.5 & 0.1 \\
\hline
\end{tabular}

${ }^{1}$ percentage of albumen tested, calculated in relation to the final volume of $10.6 \mathrm{~mL}$. 
were incubated under microaerobic conditions (Probac microaerobic generator) in anaerobic jars at $37^{\circ} \mathrm{C}$ for $48 \mathrm{~h}$. The C. jejuni ATCC 33291 strain was used as a positive control. Colonies suspected of belonging to the genus and the specific species was determined using a multiplex PCR technique.

DNA from the colonies was extracted using a thermo-extraction procedure and amplified using primer sets I and II, as described by Gillespie et al. (2002) For the reaction, $20 \mathrm{ng}$ of DNA and other reagents (Invitrogen Brasil Ltda, São Paulo) were used, as described by Harmon et al. (1997). C. jejuni (ATCC 33291) was used as a positive control in all the amplification reactions, and the negative control was composed of sterile ultrapure water. The reaction components were amplified in the thermocycler using the conditions described by Harmon et al. (1997). At the end of the reaction, the amplified products were analyzed using electrophoresis on a 1.5\% agarose gel, stained with SYBR Safe solution (Invitrogen Brasil Ltda), using $0.5 \mathrm{x}$ TBE running buffer at $8 \mathrm{~V} / \mathrm{m}$. The gel was visualized under UV light in a transilluminator system with photodocumentation capability.

To confirm that the $C$.jejuni colonies recovered from the samples were those previously inoculated experimentally, the recovered colonies, the strain originally inoculated, a positive control of C. jejuni ATCC 33291 and a negative control (natural isolate of $C$. coli) were analyzed using the random amplification of polymorphic DNA (RAPD) technique.

The DNA was extracted by thermal treatment and quantified using a spectrophotometer. The primer used, 5'-GTGGATGCGA-3', was synthesized by Invitrogen Brasil Ltda: 1290 (Akopyanz et al., 1992). The final amplification reaction volume was $20 \mu \mathrm{L}$ : $10 \mathrm{ng}$ of bacterial DNA, 1x amplification buffer, $2.0 \mathrm{mM} \mathrm{MgCl} 2,1 \mathrm{U}$ Taq DNA polymerase, $200 \mathrm{mM}$ triphosphate (dNTP) and 30 pmol of each deoxynucleotide (Invitrogen Brasil Ltda). The amplification was performed in a thermocycler (Eppendorf) under the following conditions: one initial cycle at $92^{\circ} \mathrm{C}$ for $2 \mathrm{~min}$, then 35 cycles, each consisting of the steps: $92^{\circ} \mathrm{C}$ for $15 \mathrm{~s}, 36^{\circ} \mathrm{C}$ for $1 \mathrm{~min}$, and $72{ }^{\circ} \mathrm{C}$ for $1 \mathrm{~min}$, and one final cycle at $72^{\circ} \mathrm{C}$ for $5 \mathrm{~min}$. The amplified products and a $100 \mathrm{bp}$ molecular weight marker (DNA Ladder, Invitrogen Brasil Ltda) were analyzed by electrophoresis on a $1.5 \%$ agarose gel, stained with SYBR Safe solution (Invitrogen Brasil Ltda) using a $0.5 \mathrm{x}$ TBE running buffer. The agarose gel was visualized under UV light in the transilluminator with a photodocumentation system.

We used descriptive statistics and calculated the samples positive for Campylobacter by PCR and plate cultivations as a percentage. The kappa coefficient $(\mathrm{p}<0.05)$ was calculated with BioStat 5.0 to compare the results obtained from the traditional culture plating to those obtained from the PCR assays.
Experimental procedures followed the guidelines of the Comitê de Ética na Utilização de Animais (CEUA) da Universidade Federal de Uberlândia, number 057/09 and number 323/09.

\section{Results and Discussion}

All results found in plate culture exhibited 100\% replicability of the results of real-time PCR. There was no recovery of bacteria in egg yolk from commercial eggs in contact with wood shavings, nor in eggs inoculated with $C$. jejuni on the outer shell membrane.

In order to check if the albumen had an inhibitory effect on the viability of $C$. jejuni, we used several albumen concentrations, and there was $100 \%$ of positivity of $C$. jejuni in all concentrations from SPF and commercial albumen eggs. However, the amount of bacteria found in the CFU was inversely proportional to the amount of albumen (Figure 1).

Unlike what occurred with commercial eggs, $C$. jejuni was able to pass through the pores of SPF eggs and remain viable up to the 3 -h point. Of the 30 eggs measured within 3 h, 20\% (5/30) were positive for $C$. jejuni. The results of RAPD-PCR showed that there was $100 \%$ similarity between the inoculated strain and the strains isolated from SPF eggs. This result proves the possibility of penetration of Campylobacter in eggs placed in contact with the bacteria and the viability of the eggs inside for up to $3 \mathrm{~h}$.

There was no recovery of bacteria in egg yolk from commercial eggs. These findings are in agreement with Paula et al. (2009), who also found no C. jejuni in commercial eggs that remained in contact with the bacteria culture when inoculated on the membrane of the shell.

The albumen is not a favorable environment for growth of microorganisms due to the presence of enzymes such as lysozyme, avidin, ovoflavoprotein, and ovotransferrin, which have antimicrobial activity directly or indirectly (Cogan et al., 2001). In this study, we found that the components of albumen are not sufficient to totally inhibit the growth of $C$. jejuni. However, to verify the effect of albumen on $C$. jejuni, we used the optimal temperature for growth. It may be that in practical situations the albumen is

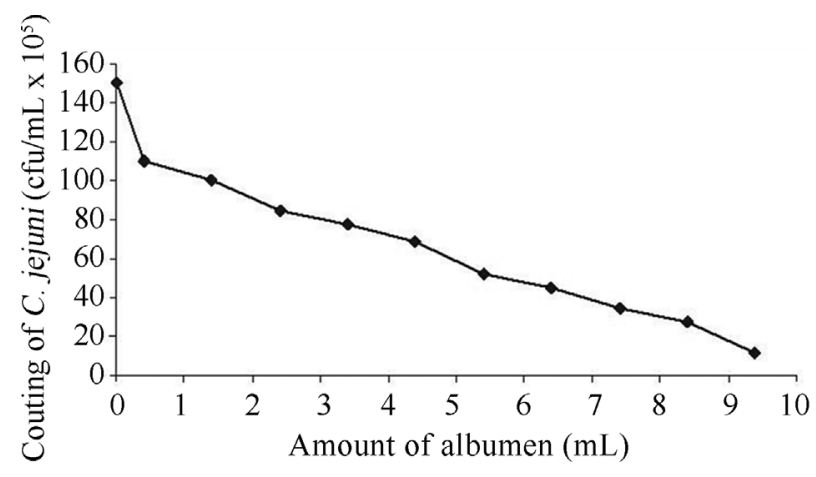

Figure 1 - Quantification of C. jejuni in different amounts of albumen. 
associated with non-ideal temperature for bacteria, thus inhibiting their growth. These findings suggest that the fertility of the egg is a decisive factor in the positive samples, because only in SPF fertile eggs were bacteria recovered, a finding similar to that found by Fonseca et al. (2007).

Despite the low percentage of positive in SPF eggs, evidence of the passage of bacteria present in the wood shavings into the interior of SPF eggs may be related to the characteristics of the egg and this microorganism. The motility of the bacteria and its size, equivalent to 0.2 to $0.8 \mu \mathrm{m}$ in width by 0.5 to $5 \mu \mathrm{m}$ in length (Vandamme et al., 1992), indicate that it is possible to pass through an egg shell's pores, which have an average diameter of $11 \mu \mathrm{m}$ to $12 \mu \mathrm{m}$.

A factor to consider about the absence of the pathogen at subsequent times ( 7 and $24 \mathrm{~h}$ ) in SPF eggs and at all times in commercial eggs is a consequence of immunity of maternal origin. This hypothesis is based on the work of Sahin et al. (2002) stressing the importance of maternal immunity and the fragile nature of the bacteria, making it uncultivable during a relatively short period after infection. It may be that maternal immunity is crucial in the negativity of commercial eggs and that in SPF eggs, this immunity has not so much interference or has an association later. But this study did not collect enough data to confirm this speculation. It is possible that temperature, associated with other factors such as the fertility of the eggs and characteristics of the eggs, has an important role in inhibiting the presence of bacteria.

Some studies have reported the difficulty of isolating bacteria of the genus Campylobacter in eggs. Doyle (1984) did not find Campylobacter spp. in the internal contents of eggs after they remained in contact with a bacteria culture at three different temperatures. Baker et al. (1987), Rabie (1992), and Zaki and Redda (1995) also failed to isolate Campylobacter in egg yolk. Sahin et al. (2002) demonstrated that $C$. jejuni has limited ability to penetrate the egg shell in the same breeding that eliminated the organism in feces.

Birds are the main reservoirs of C. jejuni, and consumption of chicken meat is implicated as the main disseminator of campylobacteriosis in humans. However, this study shows that despite the bacteria being able to penetrate the SPF egg shell and survive in the albumen environment, it is not able to penetrate and remain viable within the commercial egg temperature of $25^{\circ} \mathrm{C}$. Some associated factors seem to prevent the bacteria from penetrating and surviving in commercial eggs, and thus the consumption of infertile eggs is not a risk for campylobacteriosis in humans.

\section{References}

Akopyanz N, Bukanov NO, Westblom TU, Dresovich S, Berg DE (1992) DNA diversity among clinical isolates of Helicobacter pylori detected by PCR-based RAPD fingerprinting. Nuc Acids Res 20:5137-5142.
Altekruse SF, Stern NJ, Fields PI, Swerdlow DL (1999) Campylobacter jejuni an emerging foodborne pathogen. Em Infect Dis 5:28-35.

Baker RC, Paredes MD, Qureshi RA (1987) Prevalence of Campylobacter jejuni in eggs and poultry meat in New York State. Poult Sci 66:1766-1770.

Cogan TA, Domingue G, Lappin-Scott HM, Benson CE, Woodward MJ, Humphrey TJ (2001) Growth of Salmonella Enteritidis in artificially contaminated eggs: the effects of inoculum size and suspending media. Int J Food Microbiol 70:131-141.

Doyle MP (1984) Association of Campylobacter jejuni with laying hens and eggs. Appl Environ Microbiol 47:533-536.

EFSA - European Food Safety Authority. The Community Summary Report on Trends and Sources of Zoonoses and Zoonotic Agents in the European Union in 2007, The EFSA Journal. Italy, 223- 2009.

Fonseca BB, Soncini RA, Frezza ALC, Rossi DA (2007) Campylobacter sp em mecônio de pintainhos e em cloaca de reprodutoras. Biosc J 23:128-132.

Gillespie IA, O'Brien SJ, Frost JA, Adak GK, Horby P, Swan AV, Painter MJ, Neal KR (2002) A Case-Case Comparison of Campylobacter coli and Campylobacter jejuni Infection: A Tool for Generating Hypotheses. Emer Infect Dis 8:937942.

Harmon KM, Ramsom GM, Wesley IV (1997) Differentiation of C. jejuni and C. coli by polymerase chain reaction. Mol Cell Probes 11:195-200.

Humphrey T, O’Brien S, Madsen M (2007) Campylobacters as zoonotic pathogens: a food production perspective. Int $\mathrm{J}$ Food Microbiol 117:237-57.

Moore JE, Corcoran D, Dooley JS, Fanning S, Lucey B, Matsuda M, McDowell DA, Mégraud F, Millar BC, O’Mahony R, O'Riordan L, O'Rourke M, Rao JR, Rooney PJ, Sails A, Whyte P (2005) Campylobacter. Vet Res 36:351-382.

Paula AT, Fonseca BB, Silva MS, Rossi DA (2009) Viability of Campylobacter jejuni in commercial eggs. Bios J 25:143-148.

Rabie NSM. Studies on Campylobacteriosis in chickens. Cairo, 1992,160 p. (Ph. D. Thesis. Faculty of Veterinary Medicine. Cairo University).

Sahin O, Kobalka P, Zhang Q (2003) Detection and survival of Campylobacter in chicken eggs. J Appl Microbiol 95:1070-1079.

Sahin O, Morishita TY, Zhang Q (2002) Campylobacter colonization in poultry: sources of infection and modes of transmission. Anim Health Res Rev 3:95-105.

Users Guide BAX®System (2007) PCR assay with automated detection for bacterial screening. Du Pont Qualicon, Wilmington, DE.

Vandamme P, Vancanneyt B, Pot B, Mels L, Hoste B, Dewettinck D, Vlaes L, Van Den Borre C, Higgins R, Hommez J (1992) Polyphasic taxonomic study of the emended genus Arcobacter with Arcobacter butzleri comb. Nov. and Arcobacter skirrowii sp. Nov. an aerotolerrant bacterium isolated from veterinary speciments. Int J Syst Bacteriol Evol 42:344-356.

Zaki MM, Redda WW (1995) Campylobacteriosis in Poultry. Vet Med J Giza 43:71-76.

All the content of the journal, except where otherwise noted, is licensed under a Creative Commons License CC BY-NC. 